\title{
Stimulated nuclear import by $\beta$-like importins
}

\author{
Karen Flores and Rony Seger*
}

\author{
Address: Department of Biological Regulation, The Weizmann Institute of Science Rehovot 76100, Israel \\ * Corresponding author: Rony Seger (Rony.Seger@weizmann.ac.il) \\ Fl000Prime Reports 2013, 5:4I (doi:10.12703/P5-4I) \\ This is an open-access article distributed under the terms of the Creative Commons Attribution-Non Commercial License \\ (http://creativecommons.org/licenses/by-nc/3.0/legalcode), which permits unrestricted use, distribution, and reproduction in any medium, \\ provided the original work is properly cited. You may not use this work for commercial purposes. \\ The electronic version of this article is the complete one and can be found at: http://fl000.com/prime/reports/b/5/4 I
}

\begin{abstract}
Classic nuclear shuttling is mediated by an importin- $\alpha \cdot \beta$ heterodimer that binds to cargoes containing a nuclear localization signal, and shuttles most nuclear proteins immediately after their translation. Aside from this canonical mechanism, kariopheryn- $\beta$ s or $\beta$-like importins operate by binding to non-canonical nuclear localization signals to mediate translocation without the assistance of importin- $\alpha$. The mechanism by which these components operate is much less understood and is currently under investigation. Recently, several $\beta$-like importins have been implicated in the stimulated nuclear translocation of signaling proteins. Here, we propose that this group of importins might be responsible for the swift nuclear shuttling of many proteins following various stimuli.
\end{abstract}

\section{Mechanisms of stimulated nuclear import}

Intracellular signaling pathways transmit signals of various extracellular stimuli to their cytosolic and nuclear targets in order to induce biological responses, such as proliferation, differentiation, cell death and migration. When needed, the signals are transmitted from the cytoplasm to the nucleus via translocation of one or more components of each of the signaling pathways involved. Thus, after stimulation, a large number of signaling proteins are rapidly translocated to the nucleus to induce and regulate many nuclear processes. However, despite the importance of stimulated nuclear signaling, the mechanisms by which these components reach the nucleus upon stimulation have been elucidated only for a few signaling pathways.

Classic nuclear shuttling is mediated by an importin- $\alpha \cdot \beta$ complex that binds to cargoes containing a nuclear localization signal (NLS), consisting of mono- or bi-partite clusters of basic amino acids [1-3]. This importin- $\alpha \cdot \beta$ complex often acts as a housekeeping mechanism that shuttles most nuclear proteins immediately to the nucleus after their translation [4]. The relocalization of cargoes is followed by the dissociation of the proteins from the importins upon binding to RanGTP [5], which exports the importins back to the cytoplasm, while the cargo remains in the nucleus [6]. However, only a limited number of signaling proteins, such as NFKB [7] and ERK5 (extracellular signal-regulated kinase 5) [8-10], use this machinery for their stimulated nuclear shuttle. Aside from this canonical mechanism, importin- $\beta$ [11] or similar karyopherins, termed $\beta$-like importins [12], operate by binding to non-canonical NLSs to mediate translocation without the assistance of importin- $\alpha$. The mechanism by which these components operate is much less understood and is currently under investigation. Recently, several $\beta$-like importins have been implicated in the stimulated nuclear translocation of signaling proteins. Here, we propose that this group of importins might be responsible for the swift nuclear shuttling of many proteins following various stimuli.

\section{The mechanism of ERKI/2 translocation to the nucleus}

ERK1/2 are important signaling proteins that translocate to the nucleus upon stimulation. The rapid and robust activation of ERK1/2 allows the phosphorylation and modulation of the activity of more than 300 proteins, which are localized either in the cytoplasm or the nucleus [13-15]. These substrates are important for the induction and regulation of cellular processes, including proliferation, differentiation, and migration amongst 
others [16-19]. The sub-cellular localization of ERK1/2 plays an important role in its regulation and physiological functioning $[20,21]$. Interestingly, it was shown that the nuclear accumulation of ERK1/2 is important primarily for the induction of proliferation [22,23], while other ERK-dependent processes are mostly regulated by cytosolic molecules [24].

ERK1/2 localization, as well as the mechanisms that govern it, has been elucidated over the past decades. In resting cells, all components of the ERK1/2 cascade are localized primarily in the cytoplasm due to their interaction with different anchoring proteins [25-28] (see Figure 1). Upon stimulation, MEK1/2 phosphorylates ERK1/2 in their TEY motif, thereby inducing a conformational change resulting in the activation of

Figure I. Schematic representation of the mechanism of stimulated ERKI/2 translocation to the nucleus

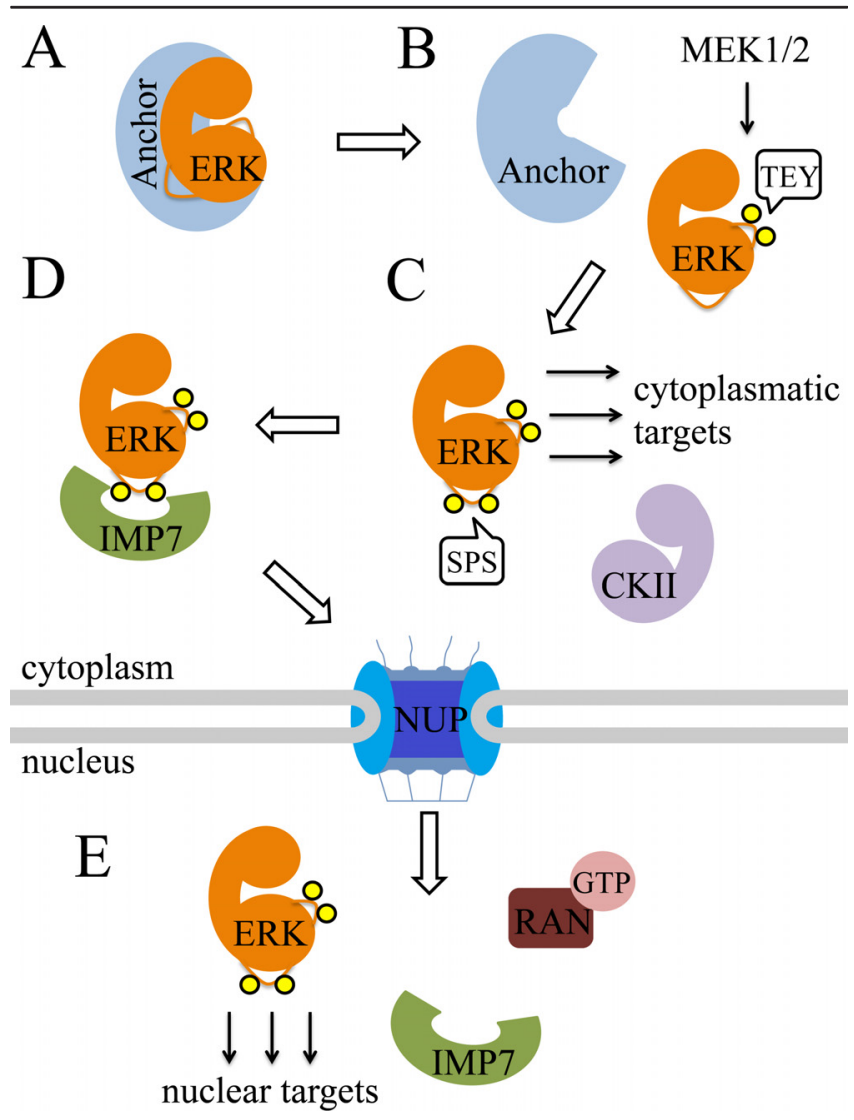

The following steps are illustrated: (A) Binding of ERKI/2 with anchor proteins in resting cells; (B) stimulation is followed by phosphorylation of the TEY motif of ERKI/2 by MEKI/2, and detachment of ERKI/2 from their anchors; (C) phosphorylation of ERKI/2 on its SPS motif by CKII. (D) Binding of phosphorylated ERKI/2 to importin-7 and nuclear sliding through the NUPs; (E) Dissociation of ERKI/2 from importin-7 by RanGTP, and nuclear accumulation of ERKI/2. For more details, see text.
ERK1/2 and detachment from their anchors [28]. This detachment exposes ERK1/2 to an additional phosphorylation on two Ser residues (an SPS motif) within a nine amino acid sequence, termed nuclear translocation signal (NTS) [29]. This phosphorylation can be mediated by both stimulated and constitutively active protein kinases, including protein kinase CK2 and auto-phosphorylation by active ERK1/2 [30]. The phosphorylation of the SPS motif allows it to bind importin-7, which escorts ERK1/2 molecules to the nuclear pores, inducing nuclear sliding. Once in the nucleus, RanGTP dissociates importin-7 from ERK1/2, and consequently, induces their nuclear accumulation [29]. It was also shown that ERK1/2 may interact directly with the nuclear pores, and it is possible that these direct interactions are able to facilitate the ERK1/2 translocation [31]. In addition, this process may be regulated by calcium, as a reduction in intracellular calcium concentrations was shown to induce faster nuclear shuttling [32,33].

Interestingly, these results in mammals were consistent with findings in Drosophila [34], where DIM-7 (the ortholog of importin-7) was identified as the carrier of D-ERK to the nucleus $[35,36]$. Once in the nucleus, ERK plays a critical role in the development of eyes and wings in Drosophila [37,38]. Moreover, while comparing the mechanism of nuclear translocation of components of the ERK cascade with other proteins, we established that the NTS might act as a specific stimulus-induced and importin-7-dependent nuclear translocation signal for some signaling proteins lacking an NLS. However, since many signaling proteins contain neither NLS nor NTS, it is possible that other ill-defined $\beta$-like importins participate in the stimulated translocation, using various non-canonical NLSs.

\section{The role of $\beta$-like importins in the nuclear shuttling of signaling proteins}

Although importin- $\alpha \cdot \beta$ complexes mediate the nuclear shuttling of a large number of proteins, it is now clear that other karyopherins are required for the translocation of the full repertoire of nuclear proteins. Such karyopherins were initially discovered as nucleoporin-binding proteins, and their homology with importin- $\beta$ suggested a function in nuclear transport [39-43], which initiated their "importin" terminology [12] (see Table 1 for nomenclature). Subsequently, more dedicated studies identified at least 10 more $\beta$-like importins in mammals that share a sequence motif related to the Ran-binding site of importin- $\beta$, and can shuttle to the nucleus under various conditions $[44,45]$. The $\beta$-like importins known today share low overall sequence identity (10-20\%), and have 19-20 helical HEAT repeats arranged into super-helical or ring-like structure [46]. Their molecular weights (90-150 kDa [46]), and 
Table I. List of $\beta$-like importins

\begin{tabular}{|c|c|c|}
\hline Importin & Other terminology & Examples of signaling cargos (not always stimulated shuttle) \\
\hline Importin-2 & $\begin{array}{l}\text { importin- } \beta 2 \text {, IPO2, KPNB2, MIP, MIPI, TNPOI, } \\
\text { transportin, transportin I, TRN, IMB2, Kap } \beta 2 \text {, } \\
\text { karyopherin- } \beta 2\end{array}$ & $\begin{array}{l}\text { c-Jun [50], NPM-ALK [57], hnRNP AI [84,85] and several } \\
\text { mRNA binding proteins [86], EWS }[87] \text {, HuR [88], c-Fos }[59,60] \text {, } \\
\text { ribosomal proteins [89]. }\end{array}$ \\
\hline Importin-3 & $\begin{array}{l}\text { Importin-3, Imp3, transportin 2, FLJI255, KPNB2B, } \\
\text { TRN2, Karyopherin } \beta-2 b \text {, IPO3, TNPO2, IMB2 }\end{array}$ & HuR $[88,90]$, hnRNP AI [9I]. \\
\hline Importin-4 & $\begin{array}{l}\text { Imp4, karyopherin-34, Imp4b, FLJ23338, MGCI3I665, } \\
\text { IPO4, IMB4, RanBP4, IMP4B }\end{array}$ & Vitamin D receptor [6I], HIFI- $\alpha$ [5I]. \\
\hline Importin-5 & $\begin{array}{l}\text { IPO5, IMB3, Psel, Imp5, RANBP5, Kap } 33, \text { KPNB3, } \\
\text { MGC2068, FLJ4304I, DKFZp686OI576, IMB3 }\end{array}$ & c-Jun [50], p60TRP [92], RAG-2 [93], ribosomal proteins [89]. \\
\hline Importin-7 & IPO7, Imp7, RANBP7, FLJI458I, MGCI38673 & $\begin{array}{l}\text { ERKI/2 [29,35], MEKI [29], SMAD3/4 [29,52], EgrI [56], HIFI } \alpha \\
{[5 \mathrm{I}] \text {, c-Jun [50], GR [54], Sox-2 [49], ribosomal proteins [89]. }}\end{array}$ \\
\hline Importin-8 & Imp8, IPO8, RANBP8, FLJ26580 & $\begin{array}{l}\text { SMADI/3/4 [52], NPM-ALK [57], Ago2 [58], glucocorticoid } \\
\text { receptor [54]. }\end{array}$ \\
\hline Importin-9 & $\begin{array}{l}\text { Imp9, FLJI 0402, IPO9, RANBP9, KIAAII 92, } \\
\text { DKFZp76IMI547 }\end{array}$ & PR65 of PP2A [94], c-Jun [50], ARX [95], Sox-2 [49]. \\
\hline Importin- II & IPOII, ImpI I, SLRN, RanBPII, KAI20 & UbcH6 [96], UB2E2 [96]. \\
\hline Importin-12 & $\begin{array}{l}\text { Imp 12, importin-12, IPOI2, MTRIOA, TNPO3, } \\
\text { transportin 3, transportin 3, transportin-SR, } \\
\text { TRN-SR, TRN-SR2, TRNSR }\end{array}$ & MLF2 [97], RBM4 [97]. \\
\hline Importin-13 & $\begin{array}{l}\text { IPOI3, Imp I3, KAPI3, RANBPI3, LGL2, } \\
\text { KIAA0724, Karyopherin I3 }\end{array}$ & c-Jun [50], ARX [95], GR [98], Mago [99], YI4 [99]. \\
\hline Exportin-4 & XPO4, Exp4, FLJI3046, KIAAAI72I & Sox-2 and SRY [49]. \\
\hline
\end{tabular}

Modified from: Eldar and Seger Mol Cell Biol (20I3), submitted.

isoelectric points $(\mathrm{pI}=4.0-5.9[46,47])$ vary. These importins mediate the translocation of proteins into the nucleus under varying conditions, including stimulation. Here, we describe the possible involvement of the $\beta$-like importins, as well as exportin- 4 , in the stimulated translocation of signaling proteins.

Among the $\beta$-like importins with the highest number of identified cargoes is importin-7, which seems to utilize several mechanisms and distinct NLSs to shuttle its distinct cargoes (Table 2). In some cases, usually in nonstimulated cells, importin-7 acts in a complex with importin- $\beta[48,49]$, or in parallel to importin-2 [50], importin-4 [51], and importin-8 [52]. However, importin-7 also acts by itself, mainly in stimulated translocations. Thus, importin-7 mediates the nuclear translocation of ERK1/2 described above, as well as MEK1 and SMAD3, by binding to the NTS sequences of these cargoes $[29,53]$. Moreover, it was reported that importin-7 is able to directly bind to a canonical NLS sequence in the glucocorticoid receptor to escort it to the nucleus upon hormonal stimulation [54]. In addition, importin-7 seems to shuttle other signaling proteins or transcription factors to the nucleus in an NTS- and canonical NLSindependent manner. Such molecules include the transcriptional regulators HIF1- $\alpha$ [51], c-Jun [50], several SMAD proteins [29,52,53], Sox-2 [49], HIV-1 [55], Egr-1 [56], and the oncogenic NPM-ALK [57]. However, it remains unclear whether the importin-7-mediated translocation of all these proteins is affected by stimulation, or is active merely in resting cells.
Table 2. Importin-cargo interactions of $\beta$-like importins

\begin{tabular}{|c|c|c|}
\hline Type of interaction & Example & Stimulated \\
\hline $\begin{array}{l}\text { Monomeric, direct } \\
\text { canonical NLS- } \\
\text { dependent cargo } \\
\text { binding. }\end{array}$ & $\begin{array}{l}\text { Importin- } 7 \text { binds the } \\
\text { canonical NLS in gluco- } \\
\text { corticoid receptor and } \\
\text { escorts it to the nucleus } \\
\text { upon stimulation [54]. }\end{array}$ & Yes \\
\hline $\begin{array}{l}\text { Monomeric, direct } \\
\text { non-canonical NLS- } \\
\text { independent cargo } \\
\text { binding. }\end{array}$ & $\begin{array}{l}\text { Importin-7 binds to } \\
\text { phosphorylated SPS } \\
\text { domain of ERKI/2 upon } \\
\text { stimulation }[29] .\end{array}$ & Yes \\
\hline $\begin{array}{l}\text { Cargo binding in } \\
\text { complex with } \\
\text { importin- } \beta \text {. Usually } \\
\text { via canonical NLS. }\end{array}$ & $\begin{array}{l}\text { Heterodimers of } \\
\text { importin- } 7 \cdot \beta \text { have been } \\
\text { implicated in the } \\
\text { nuclear accumulation of } \\
\text { Sox- } 2 \text { [49]. }\end{array}$ & No \\
\hline $\begin{array}{l}\text { Cooperation with } \\
\text { other } \beta \text {-like importins. } \\
\text { Usually bind non- } \\
\text { canonical NLSs. }\end{array}$ & $\begin{array}{l}\text { Various } \beta \text {-like importins } \\
\text { cooperate in mediating } \\
\text { nuclear translocation of } \\
\text { c-Jun }[50] \text { and SMADI/ } \\
2 / 3[52,55] \text {. No direct } \\
\text { association between } \\
\text { them was reported. }\end{array}$ & Yes \\
\hline
\end{tabular}

Although the information on other members of the family still lags behind that of importin-7, it seems that at least some of them play important roles in stimulated translocation as well. Accordingly, importin-8 was shown to induce the nuclear accumulation of Ago2 [58] and SMAD1/4 [52]. C-Jun was shown to be transported by importins 2, 5, 7, 9, and 13, that might be related, at least in part, to its stimulated nuclear accumulation [50]. Importin-2 shuttles c-Fos to the nucleus after translation [59] or upon stimulation [60], and importin-4 escorts 
vitamin $\mathrm{D}$ receptor to the nucleus upon ligand stimulation [61]. Interestingly, exportin-4, which participates mainly in nuclear export [62], has been shown to function as an importin for Sox-2, in addition to importin- $\beta \cdot 7$ and importin-9 [49]. This makes exportin-4 a distant relative of the $\beta$-like importins (Table 1), although it is not clear whether it participates in stimulated translocations as well. In general, $\beta$-like importins are able to induce both stimulated and/or non-stimulated translocations, using at least 4 mechanisms: (i) monomeric, direct canonical NLS-dependent cargo binding; (ii) monomeric, direct non-canonical NLS-independent cargo binding; (iii) cargo binding in a complex with importin- $\beta$; and (iv) cooperation with other $\beta$-like importins (see more details in Table 2). Thus, as a group, $\beta$-like importins may play an important role in the stimulated translocation of signaling proteins and transcription factors.

\section{Summary and future directions}

There is increasing evidence that the translocation of signaling proteins into the nucleus is much more tightly regulated than it was thought just a few years ago. Aside from the NLS/importin- $\alpha \cdot \beta$ machinery, other mechanisms, such as passive diffusion $[63,64]$, active transport of homodimers [64-66], direct binding to nuclear pore machinery $[31,67-70]$, escort to the nucleus by other NLS-containing proteins $[71,72]$ and indirect aid by the canonical machinery [64], were initially proposed for several signaling proteins. However, some of these findings were not properly verified, and later were either disputed [73-75], or found to be cell-type specific [76]. Therefore, it is worthwhile to entertain the possibility that at least some of these alleged mechanisms are, in fact, part of the wider $\beta$-like importin-dependent networks.

In addition, since dysregulation of the signaling proteins described above is involved in diseases, such as cancer and autoimmunity, it would be interesting to study the potential therapeutic implications of inhibiting their nuclear translocation. Several attempts have been made to block canonical NLS/importin- $\alpha \cdot \beta$ mediated nuclear translocation [77-80]. Since many proteins use this machinery to translocate to the nucleus, such inhibition might affect too many processes and may fail to develop into desired specific therapies. However, a more specific approach might be to target the non-canonical mechanism of translocation, which seems to act within a limited number of distinct proteins upon stimulation. In this direction, efforts were made to develop a blocking peptide for importin-2 [81,82]. This peptide is able to compete with natural substrates and is resistant to Ran-mediated release in the nucleus [83], therefore specifically inhibiting this process [81]. However, in order to develop strong inhibitors for a specific cargo//-like importin complex, we need to extract precise information on the structural interaction, as well as the regulation of import. We will then be able to explore this mechanism as a new layer of therapeutic intervention.

\section{References}

I. Marfori M, Mynott A, Ellis J], Mehdi AM, Saunders NFW, Curmi PM, Forwood JK, Bodén M, Kobe B: Molecular basis for specificity of nuclear import and prediction of nuclear localization. Biochim Biophys Acta 201 I, I 813:1562-77.

\section{FlOOOPrime}

RECOMMENDED

2. Frankel $M B$, Knoll LJ: The ins and outs of nuclear trafficking: unusual aspects in apicomplexan parasites. DNA Cell Biol 2009, 28:277-84.

3. Riddick G, Macara IG: A systems analysis of importin-\{alpha\}\{beta\} mediated nuclear protein import. J Cell Biol 2005, 168:1027-38.

\section{FlOOOPrime}

RECOMMENDED

4. Chook YM, Süel KE: Nuclear import by karyopherin-ß3s: recognition and inhibition. Biochim Biophys Acta 2011, 1813: 1593-606.

\section{FlOOOPrime}

RECOMMENDED

5. Moroianu J, Blobel G, Radu A: Nuclear protein import: Ran-GTP dissociates the karyopherin alphabeta heterodimer by displacing alpha from an overlapping binding site on beta. Proc Natl Acad Sci U S A 1996, 93:7059-62.

FlOOOPrime RECOMMENDED

6. Stewart M: Molecular mechanism of the nuclear protein import cycle. Nat Rev Mol Cell Biol 2007, 8:195-208.

\section{FlOOOPrime}

RECOMMENDED

7. Magnani M, Crinelli R, Bianchi M, Antonelli A: The ubiquitindependent proteolytic system and other potential targets for the modulation of nuclear factor-kB (NF-kB). Curr Drug Targets 2000, I:387-99.

8. Kondoh K, Terasawa K, Morimoto H, Nishida E: Regulation of nuclear translocation of extracellular signal-regulated kinase 5 by active nuclear import and export mechanisms. Mol Cell Biol 2006, 26: 1679-90.

9. Plotnikov A, Zehorai E, Procaccia S, Seger R: The MAPK cascades: signaling components, nuclear roles and mechanisms of nuclear translocation. Biochim Biophys Acta 201 I, I813:1619-33.

10. Nardozzi JD, Lott K, Cingolani G: Phosphorylation meets nuclear import: a review. Cell Commun Signal 2010, 8:32.

II. Xu D, Farmer A, Chook YM: Recognition of nuclear targeting signals by Karyopherin- $\beta$ proteins. Curr Opin Struct Biol 2010 , 20:782-90.

12. Ström AC, Weis K: Importin-beta-like nuclear transport receptors. Genome Biol 200I, 2:REVIEWS3008.

13. Yoon S, Seger R: The extracellular signal-regulated kinase: multiple substrates regulate diverse cellular functions. Growth Factors 2006, 24:21-44.

14. Carlson SM, Chouinard CR, Labadorf A, Lam CJ, Schmelzle K, Fraenkel E, White FM: Large-scale discovery of ERK2 substrates identifies ERK-mediated transcriptional regulation by ETV3. Sci Signal 2011, 4:rs II.

\section{FlOOOPrime} RECOMMENDED

15. Kosako H, Yamaguchi N, Aranami C, Ushiyama M, Kose S, Imamoto N, Taniguchi H, Nishida E, Hattori S: Phosphoproteomics 
reveals new ERK MAP kinase targets and links ERK to nucleoporin-mediated nuclear transport. Nat Struct Mol Biol 2009, 16:1026-35.

\section{FlOOOPrime}

\section{RECOMMENDED}

16. Shaul YD, Seger R: The MEK/ERK cascade: from signaling specificity to diverse functions. Biochim Biophys Acta 2007, I773:12/3-26.

17. Raman $M$, Chen $W$, Cobb MH: Differential regulation and properties of MAPKs. Oncogene 2007, 26:3100-12.

18. Pimienta G, Pascual J: Canonical and alternative MAPK signaling. Cell Cycle 2007, 6:2628-32.

19. Zehorai E, Yao Z, Plotnikov A, Seger R: The subcellular localization of MEK and ERK-a novel nuclear translocation signal (NTS) paves a way to the nucleus. Mol Cell Endocrinol 2010, 314:213-20.

20. Wortzel I, Seger R: The ERK Cascade: Distinct Functions within Various Subcellular Organelles. Genes Cancer 20II, 2:195-209.

21. Harding A, Tian T, Westbury E, Frische E, Hancock JF: Subcellular localization determines MAP kinase signal output. Curr Biol 2005, 15:869-73.

FlOOOPrime RECOMMENDED

22. Formstecher E, Ramos JW, Fauquet M, Calderwood DA, Hsieh JC, Canton B, Nguyen XT, Barnier JV, Camonis J, Ginsberg MH, Chneiweiss H: PEA-I5 mediates cytoplasmic sequestration of ERK MAP kinase. Dev Cell 200I, I:239-50.

\section{FlOOOPrime \\ RECOMMENDED}

23. Yao Z, Flash I, Raviv Z, Yung Y, Asscher Y, Pleban S, Seger R: Nonregulated and stimulated mechanisms cooperate in the nuclear accumulation of MEKI. Oncogene 200I, 20:7588-96.

24. Casar B, Pinto A, Crespo P: ERK dimers and scaffold proteins: unexpected partners for a forgotten (cytoplasmic) task. Cell Cycle 2009, 8:1007-13.

25. Reszka AA, Seger R, Diltz CD, Krebs EG, Fischer EH: Association of mitogen-activated protein kinase with the microtubule cytoskeleton. Proc Natl Acad Sci U S A 1995, 92:888I-5.

26. Rubinfeld H, Hanoch T, Seger R: Identification of a cytoplasmicretention sequence in ERK2. J Biol Chem 1999, 274:30349-52.

27. Zúñiga A, Torres J, Ubeda J, Pulido R: Interaction of mitogenactivated protein kinases with the kinase interaction motif of the tyrosine phosphatase PTP-SL provides substrate specificity and retains ERK2 in the cytoplasm. J Biol Chem 1999, 274:21900-7.

28. Chuderland D, Seger R: Protein-protein interactions in the regulation of the extracellular signal-regulated kinase. Mol Biotechnol 2005, 29:57-74.

29. Chuderland D, Konson A, Seger R: Identification and characterization of a general nuclear translocation signal in signaling proteins. Mol Cell 2008, 31:850-6I.

\section{FlOOOPrime \\ RECOMMENDED}

30. Plotnikov A, Chuderland D, Karamansha Y, Livnah O, Seger R: Nuclear extracellular signal-regulated kinase I and 2 translocation is mediated by casein kinase 2 and accelerated by autophosphorylation. Mol Cell Biol 20I I, 31:35I5-30.

3I. Xu L, Massagué J: Nucleocytoplasmic shuttling of signal transducers. Nat Rev Mol Cell Biol 2004, 5:209-I9.

\section{FlOOOPrime}

32. Chuderland D, Marmor G, Shainskaya A, Seger R: Calciummediated interactions regulate the subcellular localization of extracellular signal-regulated kinases. J Biol Chem 2008, 283: $11176-88$.
33. Chuderland D, Seger R: Calcium regulates ERK signaling by modulating its protein-protein interactions. Commun Integr Biol 2008, I:4-5.

34. Marenda DR, Vrailas AD, Rodrigues AB, Cook S, Powers MA, Lorenzen JA, Perkins LA, Moses K: MAP kinase subcellular localization controls both pattern and proliferation in the developing Drosophila wing. Development 2006, 133:43-5I.

\section{FlOOOPrime \\ RECOMMENDED}

35. Lorenzen JA, Baker SE, Denhez F, Melnick MB, Brower DL, Perkins LA: Nuclear import of activated D-ERK by DIM-7, an importin family member encoded by the gene moleskin. Development 200I, I28:1403-I4.

\section{FlOOOPrime}

36. Vrailas AD, Marenda DR, Cook SE, Powers MA, Lorenzen JA, Perkins LA, Moses K: smoothened and thickveins regulate Moleskin/Importin 7-mediated MAP kinase signaling in the developing Drosophila eye. Development 2006, I33:1485-94.

\section{FlOOOPrime} RECOMMENDED

37. Kumar JP, Hsiung F, Powers MA, Moses K: Nuclear translocation of activated MAP kinase is developmentally regulated in the developing Drosophila eye. Development 2003, 130:3703-I4.

38. Kumar JP, Tio M, Hsiung F, Akopyan S, Gabay L, Seger R, Shilo BZ, Moses K: Dissecting the roles of the Drosophila EGF receptor in eye development and MAP kinase activation. Development 1998, 125:3875-85.

39. Aitchison JD, Blobel G, Rout MP: Kap 104p: a karyopherin involved in the nuclear transport of messenger RNA binding proteins. Science 1996, 274:624-7.

\section{FlO0OPrime}

\section{RECOMMENDED}

40. Fornerod M, van Deursen J, van Baal S, Reynolds A, Davis D, Murti KG, Fransen J, Grosveld G: The human homologue of yeast CRMI is in a dynamic subcomplex with CAN/Nup214 and a novel nuclear pore component Nup88. EMBO J 1997, 16:807-16.

\section{FlOOOPrime \\ RECOMMENDED}

4I. Yaseen NR, Blobel G: Cloning and characterization of human karyopherin beta3. Proc Natl Acad Sci U S A 1997, 94:445 I-6.

\section{FlOOOPrime} RECOMMENDED

42. Fridell RA, Truant R, Thorne L, Benson RE, Cullen BR: Nuclear import of hnRNP AI is mediated by a novel cellular cofactor related to karyopherin-beta. J Cell Sci I997, I I0(Pt I I): I325-3I.

\section{FlOOOPrime}

\section{RECOMMENDED}

43. Rout MP, Blobel G, Aitchison JD: A distinct nuclear import pathway used by ribosomal proteins. Cell 1997, 89:715-25.

\section{FlOOOPrime \\ RECOMMENDED}

44. Görlich D, Dabrowski M, Bischoff FR, Kutay U, Bork P, Hartmann E, Prehn S, Izaurralde E: A novel class of RanGTP binding proteins. J Cell Biol 1997, 138:65-80.

\section{FlOOOPrime}

RECOMMENDED

45. Kutay U, Hartmann E, Treichel N, Calado A, Carmo-Fonseca M, Prehn S, Kraft R, Gorlich D, Bischoff FR: Identification of two novel RanGTP-binding proteins belonging to the importin beta superfamily. J Biol Chem 2000, 275:40163-8.

\section{FlOOOPrime}

\section{RECOMMENDED}

46. Chook YM, Blobel G: Karyopherins and nuclear import. Curr Opin Struct Biol 200I, I I:703-15. 
47. Görlich D, Kutay U: Transport between the cell nucleus and the cytoplasm. Annu Rev Cell Dev Biol 1999, 15:607-60.

48. Jäkel S, Albig W, Kutay U, Bischoff FR, Schwamborn K, Doenecke D, Görlich D: The importin beta/importin 7 heterodimer is a functional nuclear import receptor for histone HI. EMBO J 1999, | 8:24||-23.

\section{FlOOOPrime} RECOMMENDED

49. Gontan C, Güttler T, Engelen E, Demmers J, Fornerod M, Grosveld FG, Tibboel D, Görlich D, Poot RA, Rottier RJ: Exportin 4 mediates a novel nuclear import pathway for Sox family transcription factors. J Cell Biol 2009, I85:27-34.

\section{FIOOOPrime
RECOMMENDED}

50. Waldmann I, Wälde S, Kehlenbach RH: Nuclear import of c-Jun is mediated by multiple transport receptors. J Biol Chem 2007, 282:27685-92.

\section{FIOOOPRime
RECOMMENDED}

5I. Chachami G, Paraskeva E, Mingot J, Braliou GG, Görlich D, Simos G: Transport of hypoxia-inducible factor HIF-Ialpha into the nucleus involves importins 4 and 7. Biochem Biophys Res Commun 2009, 390:235-40.

\section{FlOOOPrime}

\section{RECOMMENDED}

52. Yao X, Chen X, Cottonham C, Xu L: Preferential utilization of Imp7/8 in nuclear import of Smads. J Biol Chem 2008, 283: 22867-74.

\section{FlOOOPrime}

\section{RECOMMENDED}

53. Chen X, Xu L: Mechanism and regulation of nucleocytoplasmic trafficking of smad. Cell Biosci 20II, I:40.

\section{FlOOOPrime}

\section{RECOMMENDED}

54. Freedman ND, Yamamoto KR: Importin 7 and importin alpha/ importin beta are nuclear import receptors for the glucocorticoid receptor. Mol Biol Cell 2004, I 5:2276-86.

\section{FlOOOPrime}

\section{RECOMMENDED}

55. Fassati A, Görlich D, Harrison I, Zaytseva L, Mingot J: Nuclear import of HIV-I intracellular reverse transcription complexes is mediated by importin 7. EMBO J 2003, 22:3675-85.

56. Chen J, Liu MY, Parish CR, Chong BH, Khachigian L: Nuclear import of early growth response-I involves importin-7 and the novel nuclear localization signal serine-proline-serine. Int J Biochem Cell Biol 20II, 43:905-12.

57. Wu F, Wang P, Young LC, Lai R, Li L: Proteome-wide identification of novel binding partners to the oncogenic fusion gene protein, NPM-ALK, using tandem affinity purification and mass spectrometry. Am J Pathol 2009, I 74:36I-70.

58. Weinmann L, Höck J, Ivacevic T, Ohrt T, Mütze J, Schwille P, Kremmer $E$, Benes V, Urlaub H, Meister G: Importin 8 is a gene silencing factor that targets argonaute proteins to distinct mRNAs. Cell 2009, I36:496-507.

\section{FlOOOPrime
RECOMMENDED}

59. Arnold M, Nath A, Wohlwend D, Kehlenbach RH: Transportin is a major nuclear import receptor for c-Fos: a novel mode of cargo interaction. J Biol Chem 2006, 28 I:5492-9.

\section{FlOOOPrime}

60. Higashi $N$, Kunimoto $H$, Kaneko S, Sasaki T, Ishii M, Kojima H, Nakajima K: Cytoplasmic c-Fos induced by the YXXQ-derived
STAT3 signal requires the co-operative MEK/ERK signal for its nuclear translocation. Genes Cells 2004, 9:233-42.

\section{FlOOOPrime
RECOMMENDED}

6I. Miyauchi $Y$, Michigami T, Sakaguchi N, Sekimoto T, Yoneda $Y$, Pike JW, Yamagata M, Ozono $\mathrm{K}$ : Importin 4 is responsible for ligand-independent nuclear translocation of vitamin D receptor. J Biol Chem 2005, 280:4090I-8.

\section{FlOOOPrime \\ RECOMMENDED}

62. Lipowsky G, Bischoff FR, Schwarzmaier P, Kraft R, Kostka S, Hartmann E, Kutay U, Görlich D: Exportin 4: a mediator of a novel nuclear export pathway in higher eukaryotes. EMBO J 2000, 19:4362-7|.

\section{FIOOOPrime
RECOMMENDED}

63. Harootunian AT, Adams SR, Wen W, Meinkoth JL, Taylor SS, Tsien RY: Movement of the free catalytic subunit of CAMPdependent protein kinase into and out of the nucleus can be explained by diffusion. Mol Biol Cell 1993, 4:993-1002.

64. Adachi M, Fukuda M, Nishida E: Two co-existing mechanisms for nuclear import of MAP kinase: passive diffusion of a monomer and active transport of a dimer. EMBO J 1999, I 8: 5347-58.

65. Melen K, Kinnunen L, Julkunen I: Arginine/lysine-rich structural element is involved in interferon-induced nuclear import of STATs. J Biol Chem 200I, 276: I6447-55.

66. Khokhlatchev AV, Canagarajah B, Wilsbacher J, Robinson $M$, Atkinson M, Goldsmith E, Cobb $\mathrm{MH}$ : Phosphorylation of the MAP kinase ERK2 promotes its homodimerization and nuclear translocation. Cell 1998, 93:605-I5.

67. Fagotto F, Glück U, Gumbiner BM: Nuclear localization signalindependent and importin/karyopherin-independent nuclear import of beta-catenin. Curr Biol 1998, 8:181-90.

68. Xu L, Alarcón C, Cöl S, Massagué J: Distinct domain utilization by Smad3 and Smad4 for nucleoporin interaction and nuclear import. J Biol Chem 2003, 278:42569-77.

69. Matsubayashi Y, Fukuda M, Nishida E: Evidence for existence of a nuclear pore complex-mediated, cytosol-independent pathway of nuclear translocation of ERK MAP kinase in permeabilized cells. J Biol Chem 200I, 276:4I755-60.

70. Whitehurst AW, Wilsbacher JL, You Y, Luby-Phelps K, Moore MS, Cobb MH: ERK2 enters the nucleus by a carrier-independent mechanism. Proc Natl Acad Sci U S A 2002, 99:7496-50I.

7I. Kawashima T, Bao YC, Nomura Y, Moon Y, Tonozuka Y, Minoshima Y, Hatori T, Tsuchiya A, Kiyono M, Nosaka T, Nakajima H, Williams DA, Kitamura T: Racl and a GTPase-activating protein, MgcRacGAP, are required for nuclear translocation of STAT transcription factors. J Cell Biol 2006, I 75:937-46.

\section{FlOOOPrime}

RECOMMENDED

72. Williams CC, Allison JG, Vidal GA, Burow ME, Beckman BS, Marrero L Jones FE: The ERBB4/HER4 receptor tyrosine kinase regulates gene expression by functioning as a STAT5A nuclear chaperone. J Cell Biol 2004, 167:469-78.

\section{FlOOOPrime
RECOMMENDED}

73. Wolf I, Rubinfeld H, Yoon S, Marmor G, Hanoch T, Seger R: Involvement of the activation loop of ERK in the detachment from cytosolic anchoring. J Biol Chem 200I, 276:24490-7.

74. Lidke DS, Huang F, Post JN, Rieger B, Wilsbacher J, Thomas JL, Pouysségur J, Jovin TM, Lenormand P: ERK nuclear translocation 
is dimerization-independent but controlled by the rate of phosphorylation. J Biol Chem 2010, 285:3092-102.

FlOOOPrime
RECOMMENDED

75. Casar B, Pinto A, Crespo P: Essential role of ERK dimers in the activation of cytoplasmic but not nuclear substrates by ERKscaffold complexes. Mol Cell 2008, 31:708-2I.

\section{FlOOOPrime} RECOMMENDED

76. Ranganathan A, Yazicioglu MN, Cobb MH: The nuclear localization of ERK2 occurs by mechanisms both independent of and dependent on energy. J Biol Chem 2006, 28 I: 15645-52.

77. Kosugi S, Hasebe M, Entani T, Takayama S, Tomita M, Yanagawa H: Design of peptide inhibitors for the importin alpha/beta nuclear import pathway by activity-based profiling. Chem Biol 2008, I5:940-9.

\section{FlOOOPrime}

78. Hintersteiner M, Ambrus G, Bednenko J, Schmied M, Knox AJS, Meisner N, Gstach H, Seifert J, Singer EL, Gerace L, Auer M: Identification of a small molecule inhibitor of importin $\beta$ mediated nuclear import by confocal on-bead screening of tagged one-bead one-compound libraries. ACS Chem Biol 2010, 5:967-79.

79. Ambrus G, Whitby LR, Singer EL, Trott O, Choi E, Olson AJ, Boger DL, Gerace L: Small molecule peptidomimetic inhibitors of importin $\alpha / \beta$ mediated nuclear transport. Bioorg Med Chem 2010, I8:76II-20.

80. Soderholm JF, Bird SL, Kalab P, Sampathkumar Y, Hasegawa K, Uehara-Bingen M, Weis K, Heald R: Importazole, a small molecule inhibitor of the transport receptor importin- $\beta$. ACS Chem Biol 20II, 6:700-8.

81. Cansizoglu AE, Lee BJ, Zhang ZC, Fontoura BMA, Chook YM: Structure-based design of a pathway-specific nuclear import inhibitor. Nat Struct Mol Biol 2007, 14:452-4.

82. Süel KE, Gu H, Chook YM: Modular organization and combinatorial energetics of proline-tyrosine nuclear localization signals. PLoS Biol 2008, 6:el37.

83. Chook YM, Jung A, Rosen MK, Blobel G: Uncoupling Kapbeta2 substrate dissociation and ran binding. Biochemistry 2002, 41:6955-66.

84. Siomi MC, Eder PS, Kataoka N, Wan L, Liu Q, Dreyfuss G: Transportin-mediated nuclear import of heterogeneous nuclear RNP proteins. J Cell Biol 1997, I38: I 181-92.

85. Pollard VW, Michael WM, Nakielny S, Siomi MC, Wang F, Dreyfuss G: A novel receptor-mediated nuclear protein import pathway. Cell 1996, 86:985-94.
86. Bonifaci N, Moroianu J, Radu A, Blobel G: Karyopherin beta2 mediates nuclear import of a mRNA binding protein. Proc Natl Acad Sci U S A 1997, 94:5055-60.

87. Zakaryan RP, Gehring $\mathrm{H}$ : Identification and characterization of the nuclear localization/retention signal in the EWS protooncoprotein. J Mol Biol 2006, 363:27-38.

88. Güttinger S, Mühlhäusser P, Koller-Eichhorn R, Brennecke J, Kutay U: Transportin2 functions as importin and mediates nuclear import of HuR. Proc Natl Acad Sci U S A 2004, 101:2918-23.

89. Jäkel S, Görlich D: Importin beta, transportin, RanBP5 and RanBP7 mediate nuclear import of ribosomal proteins in mammalian cells. EMBO J 1998, I7:449I-502.

90. van der Giessen K, Gallouzi I: Involvement of transportin 2mediated HuR import in muscle cell differentiation. Mol Biol Cell 2007, 18:2619-29.

9I. Rebane A, Aab A, Steitz JA: Transportins I and 2 are redundant nuclear import factors for hnRNP Al and HuR. RNA 2004, 10:590-9.

92. Heese K, Yamada T, Akatsu H, Yamamoto T, Kosaka K, Nagai Y, Sawada $T$ : Characterizing the new transcription regulator protein p60TRP. J Cell Biochem 2004, $91: 1030-42$.

93. Ross $A E$, Vuica $M$, Desiderio $S$ : Overlapping signals for protein degradation and nuclear localization define a role for intrinsic RAG-2 nuclear uptake in dividing cells. Mol Cell Biol 2003, 23:5308-19.

\section{FIOOOPRime}

94. Lubert EJ, Sarge KD: Interaction between protein phosphatase $2 A$ and members of the importin beta superfamily. Biochem Biophys Res Commun 2003, 303:908-13.

95. Lin W, Ye W, Cai L, Meng X, Ke G, Huang C, Peng Z, Yu Y, Golden JA, Tartakoff AM, Tao T: The roles of multiple importins for nuclear import of murine aristaless-related homeobox protein. J Biol Chem 2009, 284:20428-39.

96. Plafker SM, Macara IG: Importin-I I, a nuclear import receptor for the ubiquitin-conjugating enzyme, UbcM2. EMBO J 2000, 19:5502-13.

97. Lai M, Kuo H, Chang W, Tarn W: A novel splicing regulator shares a nuclear import pathway with SR proteins. EMBO J 2003, 22:1359-69.

98. Tao T, Lan J, Lukacs GL, Haché RJG, Kaplan F: Importin 13 regulates nuclear import of the glucocorticoid receptor in airway epithelial cells. Am J Respir Cell Mol Biol 2006, 35:668-80.

99. Bono F, Cook AG, Grünwald M, Ebert J, Conti E: Nuclear import mechanism of the EJC component Mago-YI4 revealed by structural studies of importin I3. Mol Cell 2010, 37:2 II-22. 